\title{
ЧАЛГАЏИЈАТА КАКО СОЗДАВАЧ/КРЕАТОР
}

Апстракт: Една од важните специфики на народната песна е тоа дека е творба на којашто не се знае нејзиниот создавач, односно дека има свој создавач во својата почетна форма и процес на создавање, но најчесто, со текот на времето се заборава неговото име. По нејзиното создавање, песната се препушта на колективот, кој ја пее, а низ филтерот на колективот таа се надоградува, се дооформува (се додаваат или одземаат елементи), и на таков начин се создаваат нејзините варијанти. Тоа е процесот на обнародување на песната, процес присутен и кај македонските чалгиски песни. За поголемиот број од нив, создавачот останал анонимен, а за извесен дел песни, создавачот е познат само меѓу одредена група луѓе.

Бидејќи не е доволно разработена и истражена оваа тема, трудот ќе се базира на малиот број податоци пронајдени во пишуваната литература, на информациите добиени од снимките што се наоѓаат на магнетофонските ленти во Архивот на Институтот за фолклор „Марко Цепенков“-Скопје, како и на оскудните податоци од документарни емисии посветени на македонската чалгиска музика.

Клучни зборови: македонска чалгија, народни песни, обнародени песни, авторизирани песни во народен дух, преработени песни.

Народната песна е олицетворение на културата на нашиот народ, односно продолжение на подадената рака на предците, која ни покажува од каде доаѓаме и која е нашата култура. Таа е отсјајот од некогашното музичкокултурно минато и нѐ води по патот на денешницата, на оваа современост во која, колку и да се оддалечуваме од некогашниот начин на живеење, сепак, секогаш се навраќаме на она што претставувало наше културно богатство.

Една од важните специфики на народната песна е тоа дека таа има свој создавач/ креатор ${ }^{1}$ во својата почетна форма и во својот процес на создавање, и таа потоа се препушта на колективот, кој ја пее и ја дооформува. Низ филтерот на колективот, народната песна се надоградува, ѝ се додаваат или ѝ се одземаат елементи, така што на крајот може да се каже дека процесот на создавањето на народните песни е динамичен процес, каде што речиси секој интерпретатор на одредена песна додава нешто свое и на таков начин често се губи, односно се заборава името на првичниот создавач. Во таа смисла,

${ }^{1}$ Тука мора да се спомне дека во овој контекст посоодветен би бил терминот создавач или креатор, а не автор, бидејќи станува збор за народна песна за која е познат создавачот на нејзината првична звучна форма, но тој создавач не поседува авторски права за таа песна. Авторските права денес се изрегулирани со Закон за авторското право и сродните права, објавен во Сл. весник на Р Македонија, бр. 115 од 31.08.2010 година. Кога авторството на песната е изрегулирано со закон, тогаш станува збор за автор, кој создал нешто, некое свое дело и поседува авторски права за делото. Затоа, во исказите на некои од истражувачите спомнати во овој труд, појавувањето, односно користењето/употребата на терминот „автор“ или „коавтор“ (во овој контекст автори/коавтори на народни песни), што е пред регулирањето на законските авторски права, не треба да доведе до забуна. 
Саздов вели: „На таа релација на своето уметничко усовршување народната песна некаде го изостава името на својот прв автор. Но, како надоместок добива безброј коавтори, кои со своите поетски дарби го доградуваат строежот на народната поетска творба“" (Саздов, 1976, 28). Овој исказ можеби повеќе се однесува на текстуалниот дел, односно на процесот на создавање на текстот, но истото може да се каже и во однос на процесот на создавање на мелодиската линија на народната песна, па на таков начин, помалку или повеќе, сите интерпретатори стануваат создавачи/ креатори. Таков е и случајот со поголемиот број чалгиски песни/ ора. За некои од нив е познат првичниот создавач, а за некои потполно е непознато кој ги создал.

Според, досега, грубото дефинирање на поимот чалгиска музика, може да се каже дека тоа е музиката што ја негувале чалгиските тајфи во македонските градови, со нагласена присутност во XIX и на почетокот на XX век, а својата присутност успеала да ја одржи и до денес. За чалгиските трубадурски охридски песни (но истото важи и за песните од другите македонски чалгиски центри, А. К.), Татаровска вели дека тие го одразуваат секојдневниот живот на луѓето од крајот во кој живеат, нивните душевни мечтаења и желби и дека кај повеќето од нив, авторот брзо се заборавал, при што добивале обележје на анонимност и варијантност, усно се пренесувале, а нивната рецепција трае и денес (Татаровска, 2001, 79). На поголемиот број од чалгиските песни и ора, создавачот не им е познат, што, како факт, кажува дека станува збор за песни/ора што биле дел од некогашниот градски музички фолклор, а преку млади ентузијасти, останале да одзвучуваат и во нашата современост, а коишто слободно можат да се класификуваат како традиционални/ народни/ староградски песни и ора. Но, тоа што на некои од нив им е познат првичниот создавач, и сепак остануваат народни, го отвора прашањето околу дефинирањето на одредени поими поврзани со оваа тематика.

Објаснувајќи го поимот народна творба во една дискусија што се водела на 24 ноември 1968 година, во рамките на програмата на Здружението на фолклористите на Македонија, Кирил Пенушлиски вели дека „секоја усна творба е плод на инспирација во даден момент на еден надарен човек што отскокнал од својата средина по своите уметнички, креативни склоности и чие име по правило останува непознато“. Понатаму вели дека „за да може една творба, што била на ваков начин создадена, да биде прифатена и да се пренесува понатаму од еден човек до друг човек, од едно место до друго место и од една генерација до друга генерација, таа мора, освен својата естетска вредност, и по дух и содржина да ги одразува погледите на народот за животот и природата, а потем и да одговара на веќеусвоените традиционални и законити сижетни, стилски и композициски (па и музички) нормативи за соодветниот жанр“. За потоа да дообјасни: „... на својот пат до нејзиното забележување скоро секоја творба е подложна на постојани промени (појава на варијантите). Всушност, бидејќи нејзиниот прв автор најчесто дава само првобитна шема на текстот (и мелодијата), таа се стилизира натаму, се усовршува и се разубавува. Се разбира, може да се случи и обратното: на својот пат до нејзиното запишување една творба да изгуби од 
својата првобитна убавина. Оттука секоја усна творба што поникнала и живеела во народот претставува процес колку индивидуален, толку и колективен“ (Пенушлиски, 1968, 319), за на крајот да ја повтори својата основна мисла дека дури откако ќе исчезне авторот, песната станува народна (Пенушлиски, 1968, 323).

Кон ова може да се додаде и тврдењето на Сотир Голабовски, кој во истата, претходноспомната дискусија на Здружението на фолклористите на Македонија, вели: „во музичкиот фолклор не спаѓаат музичките остварувања на поединци, кои заедницата ги прифатила и ги оставила неизменети, затоа што фолклорниот карактер на музиката ѝ се дава дури тогаш кога заедницата тие дела ќе ги преиначи и ќе ги преуреди“ (Голабовски, 1968, 320). Но, тука треба да се внимава на поимот преработена песна ${ }^{2}$ и да се направи дистинкција со онаа песна што се обнародила и што добила музичкофолклорен карактер, бидејќи има разлика во нивното значење.

Всушност, тука можеби може да се постави прашањето, дали спомнатите чалгиски песни и ора на кои им е познат создавачот ѝ припаѓаат на категоријата обнародени песни, поради самиот факт дека се знае кој ги создал, но и дека за нив постои доволно долга временска рамка во која се појавиле нивните варијанти поминувајќи низ увото и филтерот на народот, со извесно учество на анонимниот народен креатор во дооформувањето на звучната слика.

Ако речеме дека е така, дека тие може да се дефинираат како обнародени песни, тогаш треба да се внимава и да се разликуваат од оние песни што се авторизирани и создадени во народен дух, кои со текот на времето останале неизменети. Според досегашните согледувања, песните на кои им е познат авторот (а во поголемиот број случаи авторот и поседува авторски права) и широко се прифатени од народните маси, а притоа останале комплетно идентични на својата првобитна звучна форма не претрпувајќи никакви промени, спаѓаат во категоријата на авторизирани песни создадени во народен дух. Во дискусијата дали треба да се поддржува или не треба да се поддржува авторизирана музика што се нарекува народна, а следствено на тоа да постојат и такви фестивали каде што се создаваат „песни во народен дух“, Блаже Ристовски споменува дека ние не можеме да бидеме против такви композиции како „Македонско девојче“,, зашто се допадливи и народната

${ }^{2}$ Поимот преработена песна се однесува на тоа дека главната (основната) мелодија на една песна останува оригинална (цитирана), но се менува аранжманот на целиот музички изглед на песната. Менувањето на аранжманот во денешна смисла на зборот подразбира менување на инструментариумот, менување на хармонските прогресии доколку се присутни во претходниот аранжман, менување на мелодиските делови меѓу строфите, вметнување електронска подлога итн. Менувањето на аранжманот, всушност, може да вклучи и промена на музичкиот стил во кој ќе биде изведена песната (како на пример, една позната народна песна, со преработен аранжман може да стане поп-песна, песна во џез аранжман, песна во класичен аранжман итн.). Всушност, на таков начин, една народна песна што се преработува, добива ново музичко руво.

${ }^{3}$ Оваа песна, како и неколку други широко познати и прифатени песни од народот, како што се: „Едно име имаме“, „Ај, засвирете ми чалгии“, „Ако умрам ил загинам“, 
маса ги сака, но не смета дека тие се и народни песни, туку дека се авторизирани композиции што треба и така да се оценуваат (Ристовски, 1968, 324). Разликата меѓу авторизираните песни создадени во народен дух и чалгиските песни на кои им е познат создавачот е во тоа што првите остануваат неизменети од нивната првична звучна форма, а вторите ги доживуваат своите варијанти провлекувајќи се низ неколку генерации, иако и двата типа песни се широко прифатени од колективот и е познато кој ги создал.

Според досегашните сознанија, во македонската чалгија се споменуваат двајца од постарите попознати чалгаџии како создавачи на чалгиски песни, а тоа се Анѓеле Караѓуле (од Охрид) и Арсо Кеманеџијата (од Велес). Но, сепак, веројатно поради усното пренесување на песните, како и поради непостоење на снимен звучен пример 4 како репер за првичната музичко-текстуална идеја и форма на самите песни, се оставило простор, песните создадени од овие чалгаџии, заедницата да ги преиначи, дооформи, надгради итн. ${ }^{5}$

Според кажувањата на Кирил Кузманов-Катиљот, наведени кај Димче Маленко, создавач на попознатите охридски трубадурски песни бил Анѓеле Караѓуле. Како неговосоздадени песни се сметаат: „Песна за Деспина“, „Фанче ојде во Калишча“, „Џоџе шетат со кајчето“, „Аман, аман Катуше“, „Ке ме грабит, нане, тој Никола од Зарчета“, „Антице, мори, еребице а шчо пусти к'смет си немала“ итн. (Маленко, 1989, 8). Во истата книга, за создавањето на песната „Џоџе шетат со кајчето“, попозната како „Бог да бие Русе, твојта мајка“, има податок дека Ристо Котуш сметал дека е создадена од другарите (се мисли на другарите на Џоџе од Филевци, А. К.), а Кирил Кузманов-Катиљ тврдел дека песната е создадена од Анѓеле Караѓуле (Маленко, 1989, 21). Но, на магнетофонската лента бр. 367, Климе Садило и Наум Курте (познатите охридски чалгаџии) тврдат дека песната „Џоџе шетат со кајчето“ ја создал Климе Курте (стрико на Наум), ${ }^{6}$ па бидејќи станува збор за исказ, односно

„Ој, Вардаре македонски“ итн., се создадени од познатиот македонски автор на песни во народен дух - Јонче Христовски, (А. К.).

4 Првите звучни примери за песните создадени од охридскиот чалгаџија Анѓеле Караѓуле потекнуваат од периодот кога била актуелна тајфата на Садиловци, кои биле први наследници во негувањето на чалгискиот звук по овој ќеманеџија/чалгаџија. Првите звучни примери на песните создадени од велешкиот чалгаџија Арсо Кеманеџијата се од периодот кога била актуелна тајфата на Ало Тончов, исто така први наследници на чалгискиот звук претходно негуван од Арсо Кеманеџијата. Звучните примери се наоѓаат на магнетофонските ленти во неколку релевантни институции што поседуваат ваков тип архивски материјал. Една од тие институции е Институтот за фолклор „Марко Цепенков“-Скопје.

5 Бидејќ својата книга Охридска народна песна и приказна, во овој текст најмногу ке бидат искористени неговите податоци околу создавањето на некои од охридските чалгиски песни.

6 Климе Садило и Наум Курте (виолинисти) во дискусија со Ганчо Пајтонџиев, 25.07.1952, Охрид (интервју снимено на магнетофонска лента бр. 367, во сопственост на Архивскиот фонд на ИФМЦ). 
тврдење од постари чалгаџии, би требало да биде поверодостојно од претходните тврдења.

За песната за дертот на Осман-бег или „Излези си на пенџера мила Рисавги“, како што ја пее тајфата на Садило, меѓу народот попозната како „Ја излези, стара мајко, на пенџерето“, се вели, исто така, дека ја создал чалгаџијата Климе Курте. Во книгата на Димче Маленко се кажува дека поради тоа што не се стишувала љубовта на Осман-бег кон Рисавгија (која не му ја давале и бидејќи не сакал на сила да ја грабне за да не го навреди семејството), самиот Осман му порачал на чалгаџијата Климе Курте, недозволената љубов да ја овековечи во песна, велејќи му: „Климе, ја да ми извадиш една песна за мене и за Рисавгија, оти да знаеш дерман ќе немаш!“ Потоа пишува дека „присилен да ја правда погодената суета на бегот, чалгаџијата што ги надминал своите можности, секако не бил рамнодушен каква песна ќе пушти да се носи низ градот и по мудбаците и капиџиците тајно, на поседенките јавно“ (Маленко, 1989, 29). Исто така, песна што му се припишува на Климе Курте и на неговиот брат Стефан Курте, според Спиро Џајко (спомнат во истата книга од Димче Маленко), е и песната „Ленка пишит бела книга“"7 (Маленко, 1989, 22).

Кога станува збор за Климе Садило, досега не е потврдено со сигурност дека тој бил создавач на некоја песна или оро. Никола Бошале во својата книга за „Охридските трубадури“, вели дека „само Анѓеле Караѓуле, тој наречен Караѓуле Охридски, останал најдоминантен со својата песна и трубадурски дар и способности, додека другите повеќе или помалку останале само како инетрпретатори на неговите песни“ (Бошале, 2004, 32), а понатаму ќе каже дека „најголема заслуга што и во најтешките времиња останал жив споменот за Анѓелета Караѓуле му припаѓа на Климе Садило“ (Бошале, 2004, 84). Потоа наведува податок дека Стојан Златановски (виолинист), имал сознанија дека постои марш што го создал Садило, наречен „Маршот за Садило“ (Бошале, $2004,86)$ иако досега не е пронајден таков звучен пример. Дајреџијата Ѓоре Чочег, исто така, тврди дека не се знае за песни/ора создадени од овој чалгаџија, а тие што ги свирел ги научил од Караѓуле. ${ }^{8}$ Тоа го потврдува и Адем Бајрам, кој вели дека за разлика од Караѓуле, Садило бил „чист репродуктивец“, односно немал свои создадени песни/ора. ${ }^{9}$

Но, ако се земе за точен податокот дека е создаден таков марш од Садило, можеби тој марш не успеал да се одржи во чалгискиот градски живот, при што не ја доживеал својата варијантност и на таков начин се изгубил од меморијата на колективот. Според податокот што го кажува ќерката на

\footnotetext{
${ }^{7}$ Оваа песна некаде се сретнува и како „Ленка писа бела книга“.

8 Ѓорѓ Чочег/овски (дајреџија) во дискусија со Боривоје Џимревски, 15.02.1979, Охрид (интервју снимено на магнетофонска лента бр. 2704, во сопственост на Архивскиот фонд на ИФМЦ).

9 Адем Бајрам (виолинист) во дискусија со Боривоје Џимревски, 07.06.1987, Охрид (интервју снимено на магнетофонска лента бр. 3264, во сопственост на Архивскиот фонд на ИФМЦ).
} 
Садило, Милка Садило, во документарната емисија „Печат“, 10 Садило се јавува како создавач на: „Собарско оро“ и „Излези си на пенџера мила Рисавги“", 11 така што постојат одредени недоследности и непрецизности околу одредувањето на тоа кој бил создавачот на некои песни или ора.

Кај Татаровска се спомнува дека велешката песна посветена на белото Маре на Цинциеви, односно „Што ми е мило, мамо, сејмен да шетам низ Бузаана“, била создадена од Наце Гратчанец, добар песнарија, кој, својата тага по саканата девојка, ја преточил во песна (Татаровска, 2001, 80). Но, податокот даден кај Никофор Смилевски кажува дека оваа песна била создадена од Арсо Кеманеџијата. Според Смилевски, песни создадени од Арсо Кеманеџијата се сметаат и песните за: Султана Пулкова, за младата маџирка попозната како „Болна ми легнала младата маџирка“ и други (Смилевски, 2014, 88). Ало Тончов (познатиот велешки чалгаџија), пак, раскажува дека ја создал мелодијата на песната „Се собрале, се набрале велешките кираџии“, ${ }^{12}$ а создавач на текстот бил неговиот татко Јован. Други сведоштва за тоа кои чалгаџии се создавачи на некоја песна или на некое оро има на: магнетофонската лента бр. 29, каде што се вели дека „Рамно велешко оро“ било создадено од Ало Тончов; и на магнетофонската лента бр. 2814, каде што кеманеџијата Пане Ташев од Неготино вели дека е создавач на едно оро, што го нарекол „Неготинско оро“.

Сите овие креативни чалгиски умови, творци/ создавачи на убавите чалгиски песни и ора, остануваат да лебдат како имиња низ неколкувековната временска рамка на чалгиската историја. Градскиот дух на живеење се проткајува во секој еден стих, во секоја нота подарена од нив, создавачите, чалгаџиите, врвните мајстори на чалгијата. Сите тие чалгиски музички парчиња, за коишто се знае или не се знае (останал анонимен) создавачот, биле широко прифатени (обнародени) од колективот и одзвучуваат во музичката современост со сите нивни појавени варијанти и разни интерпретатори, како дел од македонската градска музичка култура.

\section{ЛИТЕРАТУРА}

БОШАЛЕ, Н. (2004). Охридски трубадури (Гласниции на граѓанските слободи). Охрид: Летра.

10 Милка Садило (ќерка на Климе Садило), во дискусија со водителот: Валентина Неловска, Печат (документарна емисија на телевизија ТВМ), 25.02.2015.

11 Ако се повикаме на претходнонаведениот податок дека песната за Осман-бег е создадена од Климе Курте, тоа значи дека Садило не е автор на оваа песна.

12 Песната била посветена на еден немил настан, во кој, Панче Тончов (чичкото на Ало) и Панче Мацков биле погубени од страна на Јован Бабунски, на планината Бабуна, наречена и Мукос Планина. Ова кажување е од: Ало Тончов (виолинист) во дискусија со Душко Димитровски, 05.04.1972, Велес (интервју снимено на магнетофонска лента бр. 2149, во сопственост на Архивскиот фонд на ИФМЦ); и од Ало Тончов (виолинист) во дискусија со Душко Димитровски, 14.06.1974, Велес (интервју снимено на магнетофонска лента бр. 2150, во сопственост на Архивскиот фонд на ИФМЦ). 
ГОЛАБОВСКИ, С. (1968). Терминолошки деформации во областа на музичката фолклористика. Македонски фолклор, год. I, бр. 2, 320.

МАЛЕНКО, Д. (1989). Охридска народна песна и приказна. Охрид: Завод за заштита на спомениците на културата и Народен музеј.

ПЕНУШЛИСКИ, К. (1968). За поимот народна творба. Македонски фолклор, год. І, бр. 2, 323.

РИСТОВСКИ, Б. (1968). Авторизирана народна музика. Македонски фолклор, год. І, бр. 2, 324.

САЗДОВ, Т. (1976). Македонската народна поезија (II издание). Скопје: Култура.

СМИЛЕВСКИ, Н. (2014). На којник дуќан да имам (Велешки народни песни). Скопје: Гирланда.

ТАТАРОВСКА, Л. (2001). Староградската народна песна во Македонија. Скопје: Институт за македонска литература.

Aleksandra Kuzman

\section{CHALGIAN MUSIC CREATORS}

Summary

From the analysis so far, we can notice that, besides the chalgia songs and dances were performed by the people who were nourishing the Macedonian chalgia music culture, some of them were also created from that people. Those chalgia songs and dances with known creator are widely accepted and sung/played by the collective, experiencing their variations as part of the Macedonian urban music culture and belong to the category of traditional old-urban, so-called "folklorized" songs/dances. 